Received 19.05.2017 Reviewed 22.06.2017 Accepted 18.07.2017

A - study design

B - data collection

C - statistical analysis

D - data interpretation

$\mathbf{E}$ - manuscript preparation

F - literature search

\section{Comparison between different models for rheological characterization of sludge from settling tank}

Beata MALCZEWSKA ${ }^{\text {ACDE } \bowtie}$, Adrian BICZYŃSKI ${ }^{\text {BF }}$

Wrocław University of Life Sciences, Faculty of Environmental Engineering and Geodesy, Institute of Environmental Engineering, pl. Grunwaldzki 24, 50-363 Wrocław, Poland; e-mail: beata.malczewska@upwr.edu.pl

For citation: Malczewska B., Biczyński A. 2017. Comparison between different models for rheological characterization of sludge from settling tank. Journal of Water and Land Development. No. 34 p. 191-196. DOI: 10.1515/jwld2017-0053.

\begin{abstract}
The municipal sludge characterized non-Newtonian behaviour, therefore the viscosity of the sewage sludge is not a constant value. The laboratory investigation was made using coaxial cylinder with rotating torque and gravimetric concentration of the investigated sludge ranged from $4.40 \%$ to $2.09 \%$. This paper presents the investigation on the effect of concentration of rheological sludge behaviour. The three different rheological models: Bingham (plastic model), Ostwald-de Waele (power-law), Hershel-Bulkley's were calculated by fitting the experimental data of shear stress as a function of shear rate to these models. In this study, the 3-parameter Herschel-Bulkley's model fits the experimental data best.
\end{abstract}

Key words: Herschel-Bulkley's model, rheology, sewage sludge, viscometer measurement

\section{INTRODUCTION}

Municipal wastewater treatment of sludge is a complex mixture of water-based suspension containing suspended particles, fibrous material and dissolved substances [BAROUTIAN et al. 2013]. The characteristics of the sludge vary depending on the wastewater source, treatment process, chemical additives like polymers and mechanical operations. All these factors impact on the fluid behaviour and sludge handling [BIEŃ et al. 2001; CHMIELOWSKI et al. 2016; KEMPIŃSKI, MALCZEWSKA 2005; KEMPIŃSKI, SMILGIN 2009; MALCZEWSKA 2008; MŁYŃSKI et al. 2016; SOZAŃSKI 1976; WOLSKI et al. 2010]. The complexity of the sludge composition affects its hydraulics. While typical biochemical parameters are quite well described in the literature [BIEŃ 2002; OLESZKIEWICZ 1998] comprehensive understanding of sludge rheology is not yet fully developed. Since different types of municipal sludge behave as non-Newtonian fluid, therefore there is no linear correlation between shear stress and shear rate. And the viscosity of the sewage sludge is not a constant value but it also depends on a shear rate [BIEŃ et al. 2001; KEMPIŃSKI, MALCZEWSKA 2005; KEMPIŃSKI, SMILGIN 2009; WOLSKI et al. 2010]. Moreover sewage sludge mixtures exhibited shear thinning and yield stress behaviour [FLORA et al. 2016]. Rheological models can be considered to be a mathematical equation that can describe rheological data, such as shear rate versus shear stress. Thus the main rheological parameters which play important role in optimization are the apparent viscosity and yield stress. Additionally, knowledge of the rheological characteristics of the sludge especially yield stress may be helpful to design and operating of sludge treatment process, because it allows predicting and estimating sludge behaviour.

The basic purpose to make the investigation was to define rheological properties of sludge taken from secondary settling tank, estimate the best rheological model that fits experimental data, and determination of the correlation between rheological parameters and sludge concentration. 


\section{MATERIALS AND METHODS}

\section{CHARACTERISTICS OF THE SITE}

The research was carried out on samples taken from municipal sewage treatment plant in Chociwel (Poland) from the secondary settling tank. The treatment plant has been built for city of Strzelin and is supplied with municipal and industrial wastes. Amount of supplied sewage is about $7000 \mathrm{~m}^{3} \cdot \mathrm{day}^{-1}$. The wastewater treatment is divided into two parts. One part of it is located in Strzelin. And, it is mostly mechanical treatment that consists of sewage pumping station, reservoir for transported by asenisation cars wastewater, bar screens and grit chamber. Then wastewater is transported through discharge pipe and enters the second part of treatment plant in Chociwel that consists of the primary settling tanks, activated sludge tanks, and final settling tank as well as blowers stations, channel of purified wastewater, additional equipment for chemical phosphate removal. Treatment of sludge includes a combination of thickening, digestion and dewatering processes. In a sewage treatment plant in Chociwelu the process of biological wastewater treatment is carried out by implementing low-rate activated sludge [BICZYŃSKI 2017].

The typical physic-chemical parameters of the original sludge samples were tested according to Standard Methods specified in the mandatory regulation in Poland (Ordinance of the Minister of Environmental Protection, Natural Resources and Agriculture of 18 November 2014), and on average the inflow to the wastewater treatment plant can be characterized by: $\mathrm{BOD}=252,9 \mathrm{mg} \cdot \mathrm{dm}^{-3}, \mathrm{COD}=430,0$ $\mathrm{mg} \cdot \mathrm{dm}^{-3}$, suspended solids $=280,8 \mathrm{mg} \cdot \mathrm{dm}^{-3}, \mathrm{~N}_{\text {total }}=$ $15,5 \mathrm{mg} \cdot \mathrm{dm}^{-3}$ and $P_{\text {total }}=10,6 \mathrm{mg} \cdot \mathrm{dm}^{-3}$ and the outflow from the plant can be characterized by: BOD = $4,3 \mathrm{mg} \cdot \mathrm{dm}^{-3}, \mathrm{COD}=25,8 \mathrm{mg} \cdot \mathrm{dm}^{-3}$, suspended solids $=7,3 \mathrm{mg} \cdot \mathrm{dm}^{-3}, \mathrm{~N}_{\text {total }}=2,6 \mathrm{mg} \cdot \mathrm{dm}^{-3}$ and $\mathrm{P}_{\text {total }}=0,7$ $\mathrm{mg} \cdot \mathrm{dm}^{-3}$ [BICZYŃSKI 2017].

\section{RHEOLOGICAL MEASUREMENT}

The measurements have been executed using viscometer VT550 viscometer (manufactured by Haake) with coaxial cylinder and rotating torque of CouetteSearle type. The measurement system MV1 P with measuring gap width $0.96 \mathrm{~mm}$ has been used. The results were modelled through two-parameter models both Bingham (plastic model) and Ostwald-de Waele (power-law) and using three-parameter flow model the Herschel-Bulkley model.

The gravimetric concentration of mixture $C s$ is described as mass ratio of dry component $\left(m_{s}\right)$ to the mass of a mixture $\left(m_{m}\right)$ and it was designated for each of investigated samples.

\section{RHEOLOGICAL DATA PROCESSING AND ANALYSIS}

The investigation has been performed according to method described in paper [CZABAN 1987; KEMPIŃSKI, MALCZEWSKA 2005]. However a modification of the measurement procedure was establish for the purpose of this test. All experiments were conducted following double repeated ramp tests. The protocol of measurement can be described as follows: decrease of the shear rate from 300 to $0 \mathrm{~s}^{-1}$ and return to $300 \mathrm{~s}^{-1}$ measuring at the same time the shear stress $(\mathrm{Pa})$ applied to the sludge. The apparent shear stress versus apparent shear rate and relative viscosity versus apparent shear rate flow curves (rheograms) obtained from the measurement are presented in the Figure 1.

Quantification of the experimental results of the dependence of the apparent shear stress to the apparent shear rate was evaluated by three the most recognized rheological models.

\section{CALCULATION METHODS}

In presented experiment in order to describe the flow curves the three most commonly used rheological models were used. For the analysis two parameter models like Ostwald-de Waele model and Bingham model and one model of the three-parameter's (Herschel-Bulkley model) were applied. Calculation methodology of the best fitted model is detailed in a separate paper.

\section{RESULTS AND DISCUSSION}

Many studies devoted to the rheology of sewage sludge reported its thixotropic behaviour. The timedependent shear thinning property has been reported by many researchers [BARNES 1997; BIEŃ 2002; BIEŃ et al. 2004; CAO et al. 2016]. According to TRÁVNíČEK and JUNGA [2014] the rate of thixotropy decreases with an increase of water content in the sample. PAPA et al. [2015] argued that for the proper analysis of sewage sludge rheological behaviour, the determination of the rheogram together with the hysteresis area is necessary.

The investigation has been made for series of various gravimetric concentrations $C s$ of the sludge at constant temperature. The concentration of investigated sludge ranged from $4.40 \%$ to $2.09 \%$. The Figure 1 presents the rheogram (the flow curve) for the sewage sludge concentration of $C s=3.22 \%$ (double repeated ramp test results). The collected points comprised a rheogram (decreasing and increasing curve), but they didn't form a clear hysteresis loop, which is characteristic for thixotropic behaviour. 


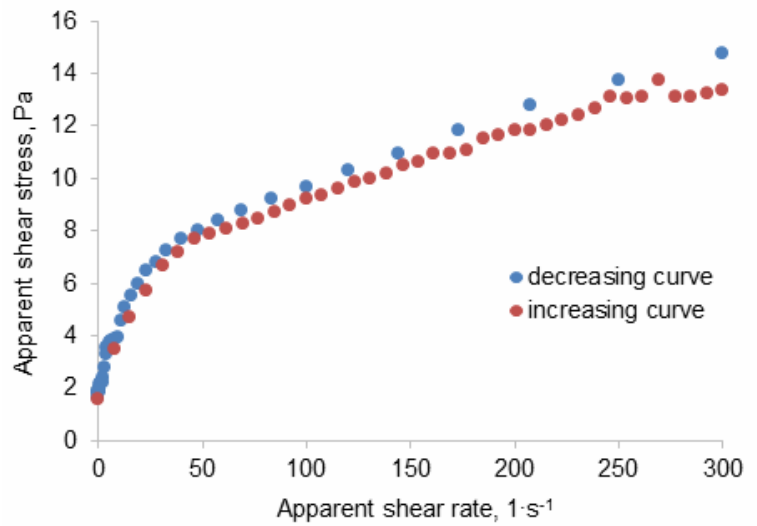

Fig. 1. An example of flow curve for the sewage sludge concentration $C s=3.22 \%$ (double repeated ramp test results); source: own study

There are several methods designed to measure the rheological behaviour of sewage sludge with different types of measuring geometry [VÍTĚZ, SEVERA 2010]. And since non-Newtonian fluids are affected by the measuring geometry, the transformation of the pseudo-curve obtained from the measurements into the true flow curve was performed. Figure 2 presents a comparison of apparent shear rate with real curves of shear stress. The difference between both curves is less than $17 \%$.

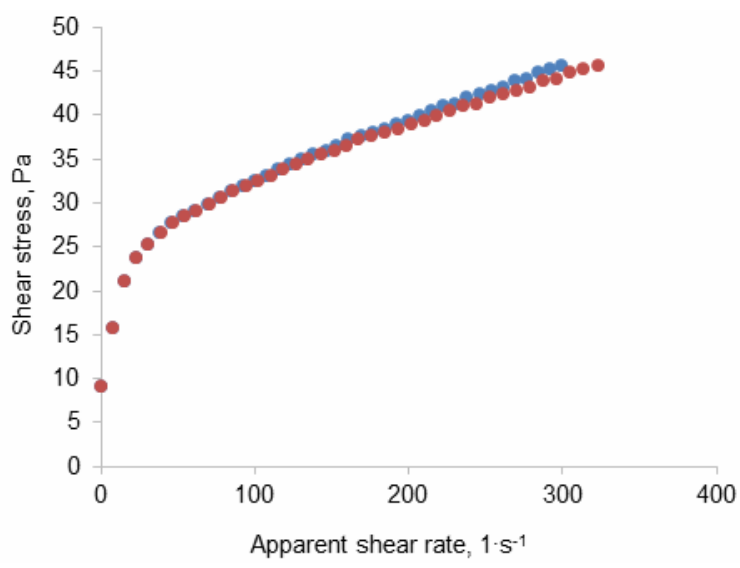

Fig. 2. Comparing apparent shear rate with real curves of shear stress; source: own elaboration

Examples of obtained apparent curves of flow (rheograms) for analysed concentrations are presented in Figures 3 and 4. The yield stress increases along with the increase in mass concentration and the apparent viscosity rapidly decreases with increasing shear rate (Fig. 3, 4). The most sudden drop in viscosity corresponds to the maximum shear stress. Presented results confirm the previous study on sludge rheology [BIEŃ 2002; BIEŃ et al. 2001; 2004; CAO et al. 2016; KEMPIŃSKI, MALCZEWSKA 2005; KEMPIŃSKI, SMILGIN 2009; MALCZEWSKA 2008].

Several mathematical models have been developed to describe the relationship between shear stress and shear rate of non-Newtonian fluids [GARAKANI 2011]. The ones most commonly used in rheo-

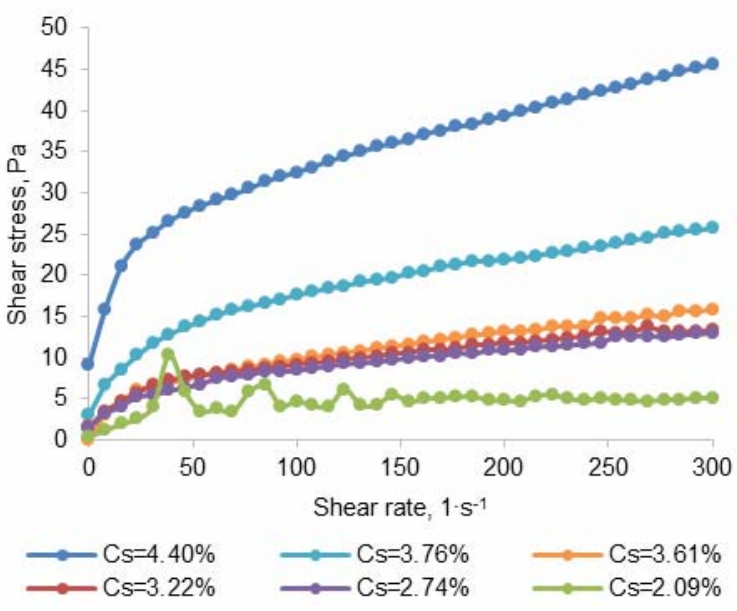

Fig. 3. Flow curve of sewage sludge concentrations $\mathrm{Cs}-$ dependence of shear stress as a function of deformation rate; source: own elaboration

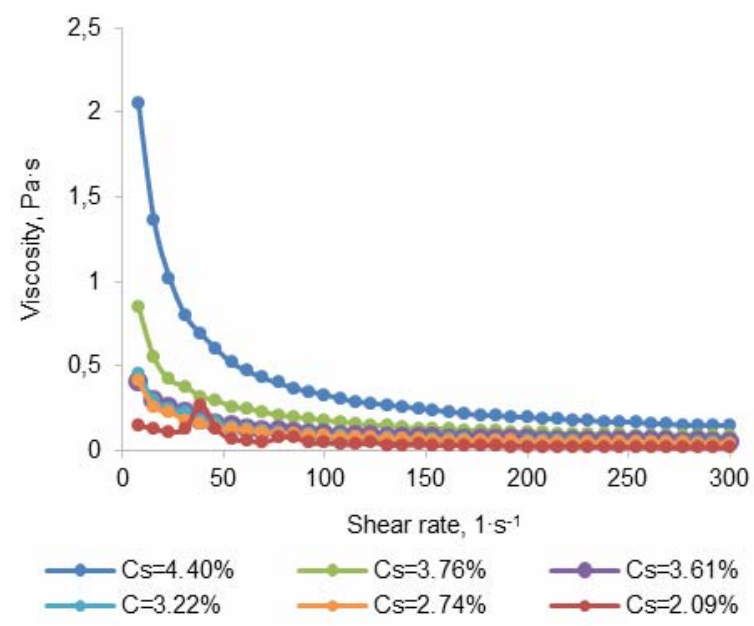

Fig. 4. Flow curve of sewage slude concentrations $C s-$ dependence of relative viscosity as a function of deformation rate source: own elaboration

logical tests are the Bingham model and the power law (Ostwald-de Waele) with each of them having two adjustable parameters. Fluids that exhibit Bingham plastic behaviour are characterized by a yield point $\left(\tau_{0}\right)$ and a plastic viscosity $(\eta)$ :

$$
\tau=\tau_{0}+\eta G_{p}
$$

A power-law fluid, or the Ostwald-de Waele relationship, is described by the following equation (where $\tau$ is the shear stress):

$$
\tau=k G_{p}^{n}
$$

The Herschel-Bulkley model is an example of a three-parameter model:

$$
\tau=\tau_{0}+k G_{p}{ }^{n}
$$

where: $\tau_{0}=$ express yield point, $\mathrm{Pa} ; k=$ rigidity coefficient, $\mathrm{Pa} \cdot \mathrm{s}^{\mathrm{n}}, n=$ a structural number.

The data obtained from experiments was approximated by Bingham, Ostwald-de Waele and Herschel-Bulkley models (Tab. 1). 
Table 1. Parameters of different rheological models with different mass concentrations and Pearson's correlation coefficient

\begin{tabular}{|l|c|c|c|c|c|}
\hline \multirow{2}{*}{ Model name } & $\begin{array}{c}C s \\
\%\end{array}$ & $\begin{array}{c}\eta \\
\mathrm{Pa} \cdot \mathrm{s}\end{array}$ & $\begin{array}{c}k \\
\mathrm{~Pa} \cdot \mathrm{s}^{\mathrm{n}}\end{array}$ & $n$ & $R$ \\
\hline Bingham model & 4.40 & 0.55620 & - & - & 0.9405 \\
\cline { 2 - 6 } (plastic model) & 3.76 & 0.05528 & - & - & 0.9424 \\
\cline { 2 - 6 } & 3.61 & 0.03778 & - & - & 0.9550 \\
\cline { 2 - 6 } & 3.22 & 0.19390 & - & - & 0.9462 \\
\cline { 2 - 6 } & 2.74 & 0.06678 & - & - & 0.9383 \\
\cline { 2 - 6 } & 2.09 & 0.00911 & - & - & 0.3128 \\
\hline \multirow{4}{*}{$\begin{array}{l}\text { Ostwald-de } \\
\text { Waele model }\end{array}$} & 4.40 & - & 16.12 & 0.2636 & 0.9806 \\
\cline { 2 - 6 } & 3.76 & - & 3.655 & 0.3387 & 0.9948 \\
\cline { 2 - 6 } & 3.61 & - & 1.518 & 0.4061 & 0.9982 \\
\cline { 2 - 6 } & 3.22 & - & 3.715 & 0.3346 & 0.9923 \\
\cline { 2 - 6 } & 2.74 & - & 0.068 & 0.9896 & 0.9378 \\
\cline { 2 - 6 } & 2.09 & - & 2.198 & 0.1736 & 0.4487 \\
\hline \multirow{4}{*}{$\begin{array}{l}\text { Herschel- } \\
\text { Bulkley }\end{array}$} & 4.40 & - & 8.657 & 0.3697 & 0.9974 \\
\cline { 2 - 6 } & 3.76 & - & 2.426 & 0.3939 & 0.9978 \\
\cline { 2 - 6 } & 3.61 & - & 1.461 & 0.4115 & 0.9982 \\
\cline { 2 - 6 } & 3.22 & - & 2.601 & 0.3996 & 0.9961 \\
\cline { 2 - 6 } & 2.74 & - & 20.27 & 0.1748 & 0.9672 \\
\cline { 2 - 6 } & 2.09 & - & 89.25 & 0.00937 & 0.4833 \\
\hline
\end{tabular}

Explanations: $C s=$ sewage sludge concentrations, $\eta=$ plastic viscosity, $k=$ rigidity coefficient, $n=$ structural number, $R=$ Pearson's correlation coefficient.

Source: own study.

The Herschel-Bulkley model is very suitable for evaluating the shear stress dependence on the shear rate, in this case. The Bingham model can be also used, but only at high shear rates, what corresponds to the results reported by BAUDEZ et al. [2011]. The Ostwald-de Waele model also fits the experimental data satisfactorily, but during the measurements all samples from the highest to the lowest concentration exhibited the presence of yield stress ( $\tau_{0}$ from 9.12 to $0.39 \mathrm{~Pa}$, respectively), that the model does not include.

The evaluation of the sludge's rheological properties at various treatment stages was also performed by many researchers [BAUDEZ et al. 2011; BIEŃ et al. 2001; 2004; CAO et al. 2016; GUIBAUD et al. 2004; KEMPIŃSKI, MALCZEWSKA 2005; MALCZEWSKA 2008; O'KeLLY 2005]. Usually when decreasing the shear rate the measured values of shear stress form a hysteresis loop indicating the thixotropic behaviour. Previously reported studies revealed that the sludge samples showed shear-thinning and thixotropic characteristics [CAO et al. 2016; GUIBAUD et al. 2004; TRAVNIČEK, JUNGA 2014].

Applied measurement protocol contributes to the reduction of thixotropic behaviour of the sludge. The results indicated that rheograms exhibited almost the same viscosity curves for both ramp-up and rampdown. NOVARINO et al. [2010] pointed, when combining two different protocols of sludge analysis, that choosing one of the protocols impacts the sludge rheology interpretation.

There are many parameters impacting sludge rheological behaviour. The temperature and the solids concentration are among the most important. The ana- lysed samples of sewage sludge exhibited yield stress and they have a power relationship with solid concentration (Fig. 5, 6, 7). Presented results confirmed that the solids concentration is the main parameter affecting rheological behaviour of the sludge.

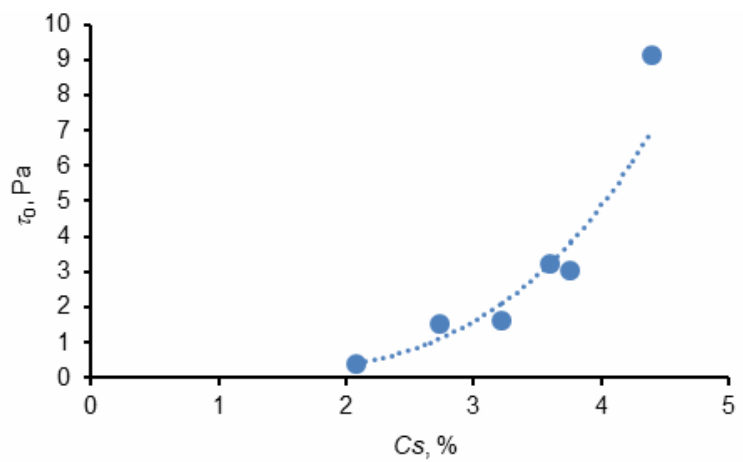

Fig. 5. Dependence of flow yield stress on sewage sludge concentration Cs for Herschel-Bulkley model; source: own study

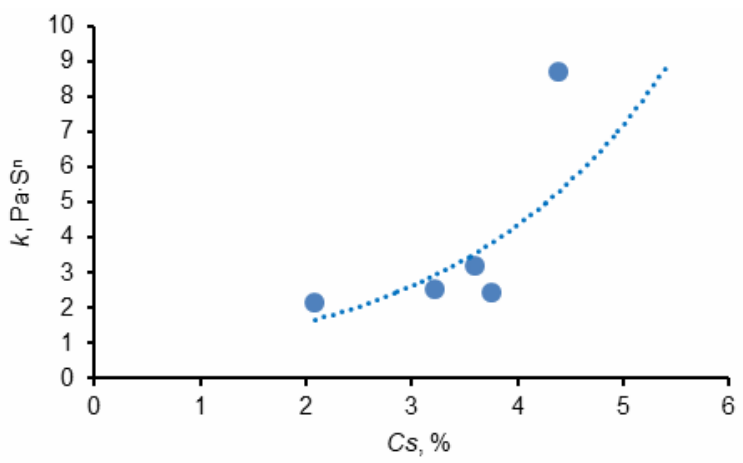

Fig. 6. Dependence of rigidity coefficient on sewage sludge concentration Cs for Herschel-Bulkley model; source: own study

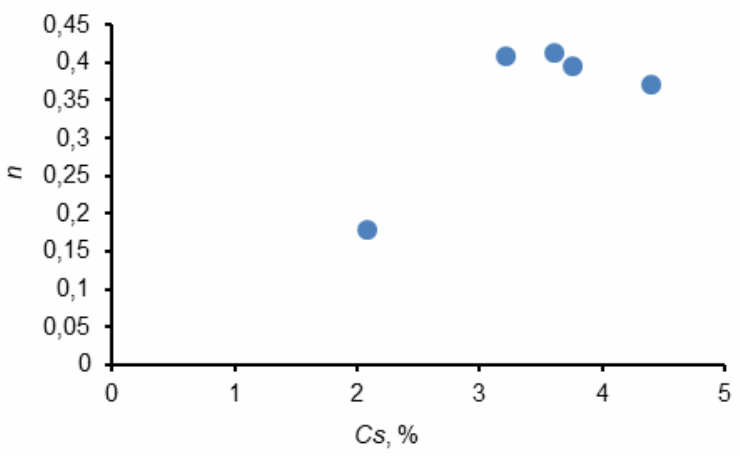

Fig. 7. Dependence of structural number on sewage sludge concentration Cs for Herschel-Bulkley model; source: own study

\section{CONCLUSIONS}

In this study, rheological characteristics were investigated for sludge from municipal wastewater treatment plant with solids concentration of $2.09 \%$, and $4.40 \%$. The analysis of the results revealed that the Herschel-Bulkley model was the most suitable 
one to describe sludge rheology for examined sludge samples. It was found that the yield stress increases with an increase in the sludge concentration as well as the rigidity coefficient of Herschel-Bulkleys' model, while the structural number does not show a clear correlation with gravimetric concentration $(C s)$. And, with increasing gravimetric concentration, pseudoplastic viscosity increased sharply at high concentration.

Presented results confirmed that solids concentration is the main parameter affecting sludge rheological behaviour and stressed the importance of choosing the appropriate measurement protocol.

Presented research can be helpful in the selection of appropriate pumps and design of treatment process. However the diversity of the wastewater composition that depends on the degree of city urbanization and many other factors contributes to the problems of choosing one universal rheological model of wastewater.

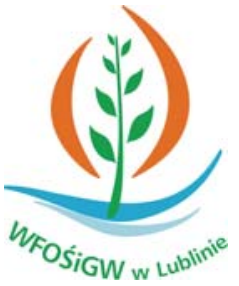

Dofinansowano ze środków Wojewódzkiego Funduszu Ochrony Środowiska i Gospodarki Wodnej w Lublinie Cofinanced by Voivodeship Fund for Environmental Protection and Water Management in Lublin

\section{REFERENCE}

BARNES H.A. 1997. Thixotropy - A review. Journal of Non-Newtonian Fluid Mechanics. Vol. 70 p. 1-33. DOI 10.1016/S0377-0257(97)00004-9.

BAROUTIAN S., ESHTIAGHI N., GAPES D.J. 2013. Rheological characteristics of a mixture of primary and secondary municipal sludge [online]. [Access 15.05.2017]. Available at: http://www.conference.net.au/chemeca2013/ papers/27510.pdf

Baudez J.C., Markis F., Eshtiaghi N., Slatter P. 2011. The rheological behaviour of anaerobic digested sludge. Water Research. Vol. 45. Iss. 17 p. 5675-5680.

BICZYŃSKI A. 2017. Wyznaczenie współczynnika lepkości w oparciu o pomiary reologiczne [Determination of coefficient of viscosity, based on rheological measurements]. MSc Thesis. Typescript. Wrocław. UP Wrocław pp. 50.

BIEŃ J.B. 2002. Osady ściekowe. Teoria i praktyka [Sewage sludge - the theory and the practice]. Częstochowa. Wydaw. PCz. ISBN 83-7193-193-X pp. 290.

BieŃ J., MatysiaK B., BieŃ J.D. 2001. Wpływ dawki wybranych polielektrolitów na właściwości reologiczne osadów ściekowych [The impact of polyelectrolyte's dose on rheological characteristic of sewage sludge]. Inżynieria i Ochrona Środowiska. T. 4. Nr 1 p. 27-39.

BieŃ J.B., MATYSIAK-BIEŃ B., BIEŃ J.D. 2004. Charakterystyki reologiczne osadów ściekowych kondycjonowanych polielektrolitami [The rheological characteristics of sewage sludge being conditioned with polyelectrolytes and ultrasonic field]. Inżynieria i Ochrona Środowiska. T. $7 . \mathrm{Nr} 3 / 4$ p. 327-339.
Cao X., Jiang Z., Cui W., Wang Y., Yang P. 2016. Rheological properties of municipal sewage sludge: Dependency on solid concentration and temperature. Procedia Environmental Sciences. Vol. 31 p. 113-121.

ChMielowski K., Bugajski P., Kaczor G.B. 2016. Comparative analysis of the quality of sewage discharged from selected agglomeration sewerage systems. Journal of Water and Land Development. No. 30 p. 35-42. DOI 10.1515/jwld-2016-0019.

CZABAN S. 1987. Wyznaczanie parametrów hydrotransportu rurowego reostabilnych mieszanin dwufazowych [Determination of parameters of hydro-pipeline reostable two-phase mixtures]. Zeszyty Naukowe AR Wrocław. Z. 60. Rozprawy. Wrocław. ISSN 0209-1321 pp. 76.

Flora M., BAudezB J-C, Parthasarathya R., Slatter P., EshTIAGHIA N. 2016. Predicting the apparent viscosity and yield stress of mixtures of primary, secondary and anaerobically digested sewage sludge: Simulating anaerobic digesters. Water Research. Vol. 100 p. 568-579.

Garakani A.H.K., Mostouf N., SAdeghi F., HosseinZadeh M., Fatourechi H., SarRafZadeh M.H., MeHRNIA M.R. 2011. Comparison between different models for rheological characterization of activated sludge. Iranian Journal of Environmental Health Science and Engineering. Vol. 8. No. 3 p. 255-264.

Guibaud G., Dollet P., Tixier N., Dagot C., Baudu M. 2004. Characterisation of the evolution of activated sludges using rheological measurements. Process Biochemistry. Vol. 39. Iss. 11 p. 1803-1810.

KeMPIŃSKi J., MALCZEWSKA B. 2005. Określenie modelu reologicznego wybranych osadów ściekowych [Developing rheological model of chosen sludges]. Acta Scientiarum Polonorum Formatio Circumiectus. $\mathrm{Nr}$ 4(1) p. 99-107.

KeMPiŃSKi J., SMILgin Z. 2009. Hydrotransport osadów ściekowych [Sewage tubular transportation]. Infrastruktura i Ekologia Terenów Wiejskich. Nr 9 p. 131-142.

MALCZEWSKA B. 2008. Badanie wybranych własności osadów ściekowych świetle możliwości ich utylizacji [Assessment of utilisation ability in agricultural area of activated sludge from municipal wastewater treatment plant]. Wrocław. Wydaw. UP we Wrocławiu. ISBN 978-83-60574-42-3 pp. 96.

MŁYŃSKi D., ChMiElowsKi K., MŁYŃSKA A. 2016. Analysis of hydraulic load of a wastewater treatment plant in Jasło. Journal of Water and Land Development. No. 28 p. 61-67. DOI 10.1515/jwld-2016-0006.

Novarino D., Santagata E., Dalmazzo D., Zanetti M. 2010. Rheological characterization of sludge coming from a wastewater treatment plant. American Journal of Environmental Sciences. Vol. 6. Iss. 4 p. 329-337.

O'Kelly B.C. 2005. Mechanical properties of dewatered sewage sludge. Waste Management. Vol. 25 p. 47-52.

OLESZKIEWICZ J.A. 1998. Gospodarka osadami ściekowymi. Poradnik decydenta [Sewage sludge management. The decision maker's guide]. Kraków. LEM. ISBN 8390896001 pp. 284

Papa M., Pedrazzani R., Nembrini S. 2015. Should rheological properties of activated sludge be measured? Applied Rheology. Vol. 25. No. 2. Article ID 24590.

SOZAŃSKI M.M. 1976. Właściwości reologiczne uwodnionych osadów pokoagulacyjnych [Rheological properties of coagulant hydrated sludges]. Wrocław. Wydaw. PWr. pp. 57.

TRÁVNÍČEK P., JUNGA P. 2014. Thixotropic behaviour of thickened sewage sludge. Journal of Environmental 
Health Science and Engineering. Vol. 12. Iss. 72 p. 1-6. DOI 10.1186/2052-336X-12-72.

VítĚZ T., SEVERA L. 2010. On the rheological characteristics of sewage sludge. Acta Universitatis Agriculturae et Silviculturae Mendelianae Brunensis. Vol. 58. No. 2 pp. 287-294.
WOLSKI P., ZAWIEJA I., WOLNY L. 2010. Wpływ temperatury na lepkość kondycjonowanych osadów ściekowych [Impact of temperature on viscosity of sewage sludge after conditioning] [online]. Proceedings of ECOpole. Vol. 4. No. 2. [Access 07.05.2017]. Available at: http://tchie.uni.opole.pl/ecoproc10b/WolskiZawieja_PE CO10_2.pdf

\section{Beata MALCZEWSKA, Adrian BICZYŃSKI}

\section{Reologiczna charakterystyka osadów ściekowych z osadnika wtórnego - porównanie modeli}

\section{STRESZCZENIE}

Komunalne osady ściekowe charakteryzują się nienewtonowskim zachowaniem, dlatego lepkość osadów ściekowych nie jest wartością stałą. W ramach określenia cech reologicznych osadów ściekowych o koncentracji w granicach od $2,09 \%$ do $4,40 \%$ przeprowadzono badania wiskozymetryczne za pomoca wiskozymetru rotacyjnego. W artykule przedstawiono wyniki badań wpływu koncentracji na zachowanie reologiczne osadu. Analizowano dopasowanie trzech najczęściej stosowanych modeli reologicznych, takich jak model Binghama (plastic model), Ostwalda-de Waele (power-law), Hershela-Bulkleya do uzyskanych rezultatów z pomiarów. Model trój-parametrowy Hershela-Bulkleya najdokładniej odpowiadał otrzymanym z pomiarów rezultatom.

Slowa kluczowe: model Herschela-Bulkleya, pomiary wiskozymetryczne, reologia osadów ściekowych 